\title{
PSYCHE
}

\begin{tabular}{lcc}
\hline Vol. 87 & 1980 & Nos. $1-2$ \\
\hline
\end{tabular}

\section{FUNCTIONAL MONOGYNY, SEXUAL BEHAVIOR, AND KARYOTYPE OF THE GUEST ANT, LEPTOTHORAX PROVANCHERI EMERY (HYMENOPTERA, FORMICIDAE)}

By Alfred Buschinger ${ }^{1}$, André Francoeur ${ }^{2}$ And Karl Fischer ${ }^{1}$

\section{1) INTRODUCTION}

The ant species Leptothorax provancheri was first detected by Provancher $(1881,1883)$ near the actual Québec metropolitan region, in the locality of Cap-Rouge, Comté de Québec, and described under the name Myrmica tuberum Fabricius. Emery (1895) recognized it as a new species to which he gave the present name. Following Creighton (1950), L. emersoni Wheeler (1901) and L. emersoni hirtipilis Wheeler (1917) are synonyms of $L$. provancheri. Thus the range of this species extends from eastern Canada and New England west to Alberta, and, with the subspecies $L$. provancheri glacialis Wheeler (1907), south to Colorado and northern New Mexico (Gregg, 1963). The subspecies glacialis is not recognized by other American myrmecologists. There is no sound basis to retain it at this moment. In the Catalog of Hymenoptera North of Mexico (U.S.N.M.), D.R. Smith did not retain it (1979). L. provancheri is allied to the subgenus Mychothorax Ruzsky, or Leptothorax sensu Smith (1950). Biological observations were made by Wheeler (1901, $1903,1910)$. From these it is known that $L$. provancheri (=emersoni) and its subspecies all are living together with host ants of the genus Myrmica, in a manner which resembles most the relations of Formicoxenus to its Formica hosts (xenobiosis). This means that $L$. provancheri constructs small nests in the earthen walls of the

\footnotetext{
${ }^{1}$ Fachbereich Biologie, Institut für Zoologie, der Technischen Hochschule, D 6100 Darmstadt, Schnittspahnstr. 3; and

${ }^{2}$ Université du Québec, Chicoutimi, Québec, Canada G7H2B1

Manuscript received by the editor September 15, 1980.
} 
Myrmica host colony, where the provancheri brood is normally kept apart from the Myrmica chambers. However, provancheri workers enter the galleries of their hosts, frequently mount the Myrmica workers, and apparently gain food by vigorously licking ("shampooing"-Wheeler 1910) and begging their victims.

Soon after the description of L. emersoni Wheeler (1901), Holliday (1903) published a very accurate and comprehensive study on the peculiar polymorphism of this little ant. She described, measured and dissected more than 1000 specimens from over 20 nests, and she discovered that only very few winged or deälate females were among them. About one third of all female individuals had to be characterized as "microgynes, ergatoid females, triocellate, biocellate and uniocellate workers", the remaining specimens were macroergates and microergates. Holliday also found out that all these ants had rather well developed ovaries, and a typical spermatheca. Surprisingly, she failed to judge whether sperm was present in the receptacula or not.

Recently we had investigated the social structures of the guest ants, Formicoxenus nitidulus (Buschinger and Winter 1976) and $F$. hirticornis (= Leptothorax hirticornis Emery) (Buschinger 1979) both of which have a polymorphism similar to that of L. provancheri, and a "functional monogyny" with always one fertile queen per nest, and often several inseminated but sterile "replacement queens" in addition. Fertile and sterile females there may either be normal, deälate queens or intermorphs, both often occurring together in the same colony. Thus we wanted to find out whether a similar system might be present in $L$. provancheri. With respect to a possible relationship between provancheri and Formicoxenus we further studied the sexual behavior, and the karyotype of this species.

\section{2) Material and Methods}

Leptothorax provancheri was collected in a moist pasture with a small rocky outcrop beside a gravel road, in the municipality of StAugustin, near the limits of Ste-Catherine, Comté de Portneuf, on 23 August 1979. The guest ant and its host had developed flourishing populations only in the rocky part of this open habitat. Colonies were located in the soil and between the roots of grass and herbs growing on the flanks and atop of the rounded rocky outcrops of the meadow. The host species, Myrmica incompleta Provancher, inhabits these 
sites in large, polygynous colonies which sometimes extend over more than $1 \mathrm{~m}^{2}$. We could regularly identify, in different Myrmica colonies, several brood chambers of provancheri, the content of which, adults and immatures, was removed carefully with an aspirator. The ants from one brood chamber, together with a few individuals crawling in the soil in the immediate vicinity of the chamber, were considered as belonging to one "colony unit". We stress that normally these colony units, found within one Myrmica nest, were clearly separated from each other by several decimeters. Nevertheless we cannot completely exclude the possibility that two chambers belonged to one colony unit (one society), or that specimens from two colony units separated by smaller distance were mixed together.

Soon after in the laboratory the numbers of males, females, intermorphs, workers, and pupae were counted (Table I). All female individuals of several representative samples were dissected and their reproductive state was evaluated as described by Buschinger and Winter (1976) and Buschinger and Alloway (1978). We prefer to define castes only by the function: queens are inseminated, fertile individuals, irrespective of their morphological aspect. The morphological differences between alate or deälate females, "workers" in the

Table I: Numbers of individuals, adults and pupae, in 15 colony units of Leptothorax provancheri, as counted immediately after collecting.

\begin{tabular}{|c|c|c|c|c|c|c|c|c|}
\hline Nr. & 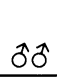 & $\begin{array}{c}\text { deälate } \\
\text { 우우 }\end{array}$ & $\begin{array}{c}\text { Inter- } \\
\text { morphs }\end{array}$ & $\begin{array}{l}\text { Ergato- } \\
\text { morphs }\end{array}$ & ऽ-pupae & $\begin{array}{c}\text { alate } \\
\text { O-pupae }\end{array}$ & $\begin{array}{c}\text { Interm. } \\
\text { pupae }\end{array}$ & $\begin{array}{c}\text { Ergatom. } \\
\text { pupae }\end{array}$ \\
\hline 1 & - & - & 1 & - & - & - & - & - \\
\hline 2 & - & 1 & 9 & 34 & 9 & - & 24 & 16 \\
\hline 3 & 3 & - & 7 & 71 & 9 & - & 5 & 15 \\
\hline 4 & 2 & - & 5 & 26 & 7 & - & - & 10 \\
\hline 5 & 22 & - & 6 & 60 & 18 & - & 11 & 27 \\
\hline 6 & - & - & 1 & 1 & - & - & - & - \\
\hline 7 & 5 & - & 9 & 36 & 10 & - & 16 & 23 \\
\hline 8 & 8 & 1 & 21 & 30 & 26 & 3 & 31 & 14 \\
\hline 9 & - & - & 3 & 6 & - & - & 1 & 8 \\
\hline 10 & 2 & - & 1 & 6 & 2 & - & - & - \\
\hline 11 & 1 & - & 3 & 21 & 6 & - & 3 & 15 \\
\hline 12 & - & - & 4 & 13 & - & - & 2 & 5 \\
\hline 13 & - & - & 13 & 29 & 7 & - & 8 & 17 \\
\hline 14 & - & - & 12 & 22 & - & - & 11 & 9 \\
\hline 15 & 1 & - & 14 & 20 & 2 & - & 19 & 7 \\
\hline$\Sigma$ & 44 & 2 & 109 & 375 & 96 & 3 & 131 & 166 \\
\hline
\end{tabular}


morphological sense, and individuals between these ("intercasts") are indicated by the terms "gynomorph", "ergatomorph" and "intermorph" (Buschinger and Winter, 1976, Buschinger 1978). The remaining colonies were kept and observed in the laboratory. From October 1979 to February 1980 they hibernated under natural temperature conditions at Darmstadt/FRG. After a severe frost period with temperatures reaching $-12^{\circ} \mathrm{C}$ many adults were dead, but could still be dissected. The larvae survived, and a small number of sexuals and workers hatched until the end of March.

Sexual behavior was observed immediately after collecting the ants in the field, and during the first half of September, in the laboratory.

Karyotype studies were made following the method of Imai, Crozier and Taylor (1977), with male pupae collected in the field.

\section{3) Female Polymorphism and Functional Monogyny}

The ant material was collected when sexual pupae and some newly eclosed sexuals were present in the nests. In Table I we did not distinguish between ergatogynes, uni-, bi- and triocellate workers, as was done by Holliday (1903); however, all these different forms did occur, alongside with alate or deälate gynomorphs and ergatomorphs without ocelli, like in the population studied by Holliday. We comprised all intermediate forms between alate/deälate females and apparently normal workers without ocelli as "intermorphs".

Table I reveals, at the first glance, that alate and deälate gynomorphs, and their pupae, are extraordinarily rare among the collected ants. Altogether we found 5 such specimens in 15 colony units, as compared to 240 intermorphs and 541 ergatomorphs. The respective numbers from Holliday (1903) are the following: queens (including microgynes): 36 , intermorphs: 411 , workers (including macroergates): 624 (These numbers, however, refer only to adults). The different numerical relations between adult intermorphs and ergatomorphs (109:375) and the immatures (131:166) in our material could indicate that workers preferably remain with their colony unit, whereas a considerable part of the intermorphs might leave the nest, mate and start new colonies. Further evidence for this interpretation is strongly provided by the dissections. Since it is difficult to include all the various combinations of different female forms and their reproductive function in a table, we will give the results of our dissections hereafter for each colony unit separately. Numbers correspond to those in table I. 
Adults of 6 samples were dissected immediately after collecting: No. 1: A single intermorph, with 3 ocelli, apparently alone in a small chamber in the host nest. Spermatheca filled with sperm, 6 ovarioles of about the length of the gaster, developing eggs. Presumably a queen independently founding a new colony.

No. 2: Colony contains a deälate, normal queen, who was observed to lay eggs. Since the colony is still alive, only a few specimens were dissected immediately after collecting: 4 callow intermorphs had only very short ovarioles $(4,5,6$ and 7 respectively), the receptacula were present, but empty. 3 workers (without ocelli) had 5 (2 $\zeta)$, and 6(1 $\zeta)$ short ovarioles, receptacula could not be found. This is different from Holliday's experiences: she found receptacula even in "microergates". However, the number of workers without receptaculum was low in our material as well (see below).

No. 6: One intermorph with dark spots at the normal position of the wings (between ergatoid female and triocellate $\zeta$ of Holliday 1903), with 6 long ovarioles, corpora lutea and the spermatheca filled with sperm - a functional queen. One $\Varangle$ with 5 ovarioles and without spermatheca. Presumably a young colony.

No. 9: One workerlike intermorph with two tiny ocelli, but 6 long ovarioles, corpora lutea, and filled spermatheca-the functional queen. 4 intermorphs with empty receptacula, 3 ergatomorphs without spermathecae, and one ergatomorph with an empty receptaculum, but with 6 ovarioles of about the length of the gaster, and a few tiny corpora lutea (egg-laying worker).

No. 11: One intermorph with 3 ocelli, the functional queen; 4 intermorphs and one ergatomorph with filled receptacula, but not egg-laying; one intermorph (callow) with empty receptaculum, 10 ergatomorphs with empty receptacula, one ergatomorph with empty receptaculum, but with corpora lutea; 3 workers without receptacula. Again a rather complete colony.

No. 12: One intermorph with 3 ocelli, the functional queen; 3 intermorphs inseminated but not egg-laying; one intermorph with empty spermatheca; 7 ergatomorphs with empty receptacula, one ergatomorph with empty spermatheca, but with corpora lutea; 2 workers without spermathecae. Complete colony.

It is striking that, notwithstanding all the uncertainties which are due to the difficult collecting of complete colonies, most of our samples (No. 2, 6, 9, 11, 12) contained one fully fertile queen, and often a number of inseminated, but sterile individuals. The latter are 
by no means always young and recently inseminated. Callows were easily distinguished from older individuals by their coloration, and by very short and thin ovarioles. Furthermore the fat body of most inseminated individuals looks somewhat different in its color from that of callows. Thus, we are sure that most of the inseminated, sterile "replacement queens" had mated during the previous year, and remained in their mother colonies. This would correspond to the "functional monogyny" in Formicoxenus (Buschinger and Winter 1976, Buschinger 1979). The results of the dissection of individuals from further 5 colonies which were kept alive until spring 1980, do also fit into this interpretation:

No. 3: 10 individuals died during hibernation and could be dissected. There was one intermorph whose spermatheca was filled with sperm, however the ovarioles were short. Two ergatomorphs exhibited the same condition. One intermorph and one ergatomorph had empty receptacula; two intermorphs and 3 ergatomorphs were found to have no spermathecae.

We suggest that, in this colony, the fertile female had died during the laboratory culture, or that the sample represents only part of a colony the queen of which was lost during collecting.

No. 4: During hibernation 17 individuals died and were dissected. Among them was one intermorph with the spermatheca filled with sperm, with 6 ovarioles of about the specimen's total length, with corpora lutea: the functional queen of this colony. 8 intermorphs were inseminated, but had short ovarioles, 2 had empty receptacula. However, among the ergatomorphs there were further two with filled receptacula, two with empty receptacula, and two without receptacula. One of the latter nevertheless was fertile, this means she had ovarioles of about half her body's length, and corpora lutea.

No. 5: 24 individuals died during hibernation. One intermorph with 8 long ovarioles, corpora lutea, and spermatheca filled with sperm, the functional queen; 9 additional intermorphs had filled receptacula, but were not egg-laying; 8 intermorphs and 3 ergatomorphs had empty receptacula; two ergatomorphs with empty receptacula and one $\zeta$ without receptaculum had small corpora lutea indicating a previous egg-laying.

No. 14: Four specimens died during hibernation: One ergatomorphic individual was the functional queen, one ergatomorph had a spermatheca filled with sperm, and two workers had no spermathecae. 
No. 15: Six individuals could be dissected; one intermorph and four ergatomorphs had empty receptacula, one worker had no spermatheca.

The remaining specimens from these 5 colonies could not be dissected because they were too much decomposed when found dead. The same happened with all individuals from colonies no. 7, 8 and 10. However, among the 5 colonies we had again 3 with one functional queen (no. $4,5,14)$, and there were inseminated but sterile specimens in these colonies, always together with a functional queen. Thus we believe that the social organization of Leptothorax provancheri, like that of Formicoxenus nitidulus (Buschinger and Winter, 1976), and F. hirticornis (Buschinger 1979), is a "functional monogyny", with always one fully fertile queen in a colony unit, and with often several inseminated but sterile "replacement queens". Such queens could possibly found own colonies by budding, together with a few workers from the mother colony. However, founding of colonies by single newly inseminated females alone may also occur (cf. no. 1). It is interesting that a few intermorphs and ergatomorphs, without being

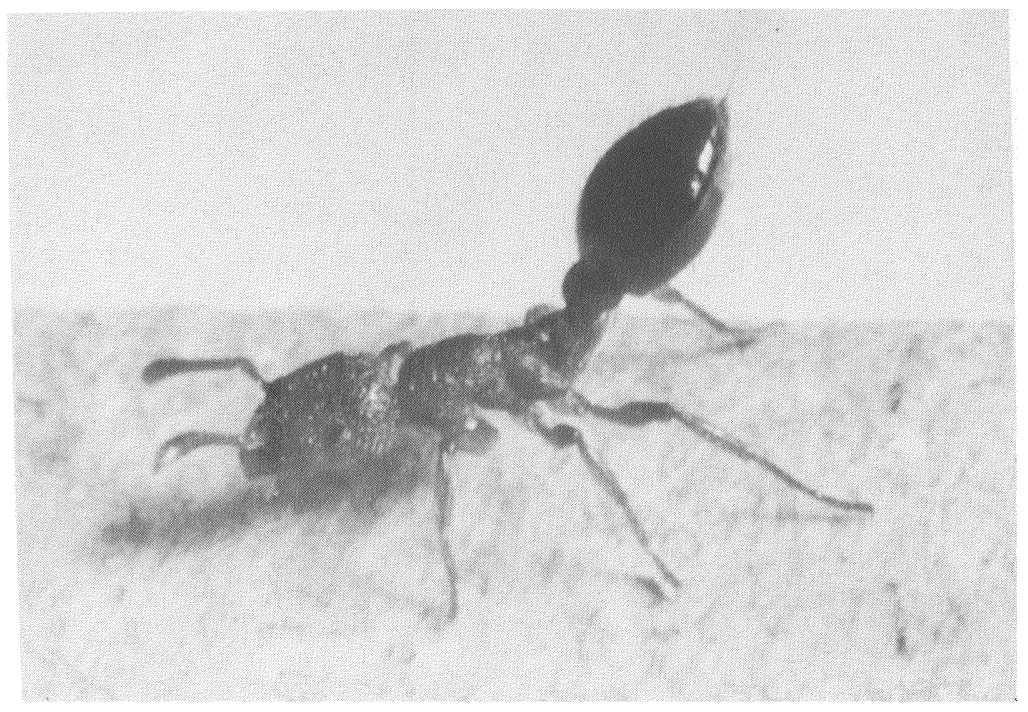

Fig. 1: Sexual calling behavior of a Leptothorax provancheri female (ocellate intermorph). The stinger is extruded. 
inseminated, may be fertile as is shown by the presence of corpora lutea in their ovarioles.

\section{4) Sexual Behavior of Leptothorax provancherI}

The sexual behavior of $L$. provancheri is, as far as observed, identical with that of Formicoxenus nitidulus (Buschinger 1976), Harpagoxenus sublaevis (Buschinger 1972) and other species of the Mychothorax group and their social parasites. This means that sexually active females emerge from the nests, climb atop of the nest chamber or any other object in the formicary, raise the gaster and present, with the stinger extruded, a sexual pheromone. With $L$. provancheri we observed, in the morning between about 9 and 11 a.m., several intermorphs and ergatomorphs exhibiting this "Locksterzel" behavior (Fig. 1). After all males had died by 15 September in colonies no. 3 and 10, the females remained active until 29 September when the colonies were put into hibernation temperatures. The males are attracted by poison gland secretion of the females, as in the other species cited above. They mount the females (Fig. 2), and the copulation differs by no means from what was observed in Formicoxenus. The behavior of alate females could not be studied.

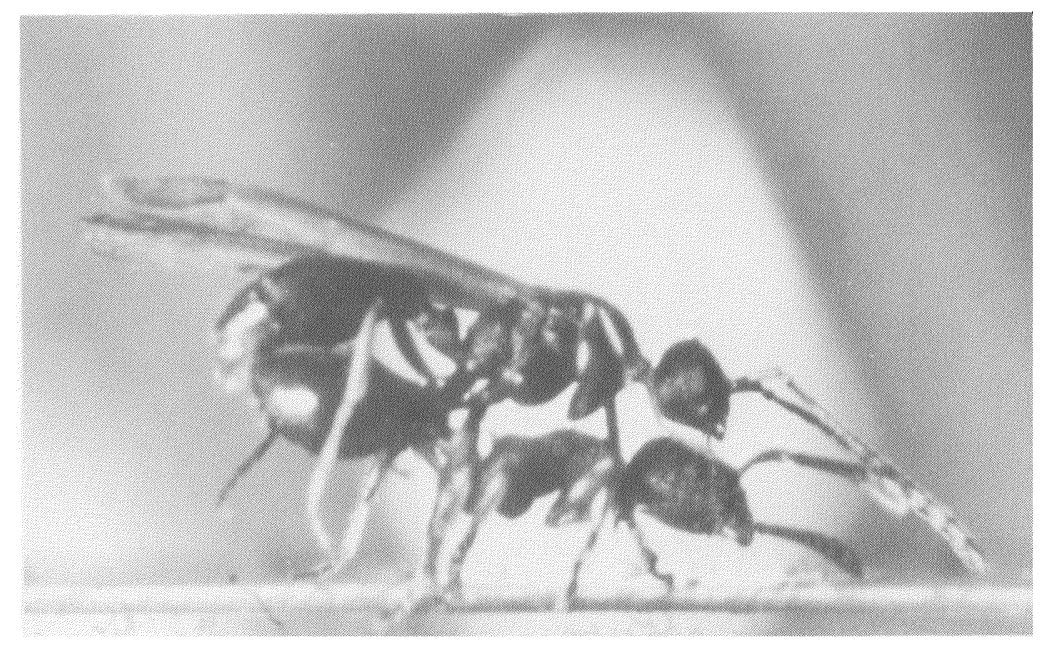

Fig. 2: L. provancheri male mounting a calling intermorph. 


\section{5) KARYOTYPE OF LEPTOTHORAX PROVANCHERI}

Nine male pupae from four colonies (colony no.1: 2 pupae, no. 2: 3 p., no. 3: 1 p., no. 8: 3 p.) were used for karyotype studies. A total of 67 metaphases were found with 11 chromosomes each, whereas two had the diploid number of 22, and two others had 8 and 21 chromosomes respectively. In the latter two cells, a haploid and a diploid one, the missing chromosomes presumably have been lost during the preparation. Thus the haploid number of chromosomes in Leptothorax provancheri males is $\mathrm{n}=11$ (Fig. 3 ). All chromosomes are metacentric or submetacentric. They range continuously in size with the smallest of about half the length of the largest. The chromosome number of Formicoxenus nitidulus is $\mathrm{n}=15$. Thus a closer relationship between L. provancheri and Formicoxenus cannot be demonstrated with a comparison of the karyotypes. However, chromosome numbers vary often between closely related species among the Leptothoracini. So, for example, Harpagoxenus sublaevis has $\mathrm{n}=20$ and Harpagoxenus canadensis $\mathrm{n}=18$, Leptothorax muscorum (Nyl.) $\mathrm{n}=17$ and $L$. gredleri Mayr, formerly synonymized with $L$. muscorum, has $\mathrm{n}=11$ !

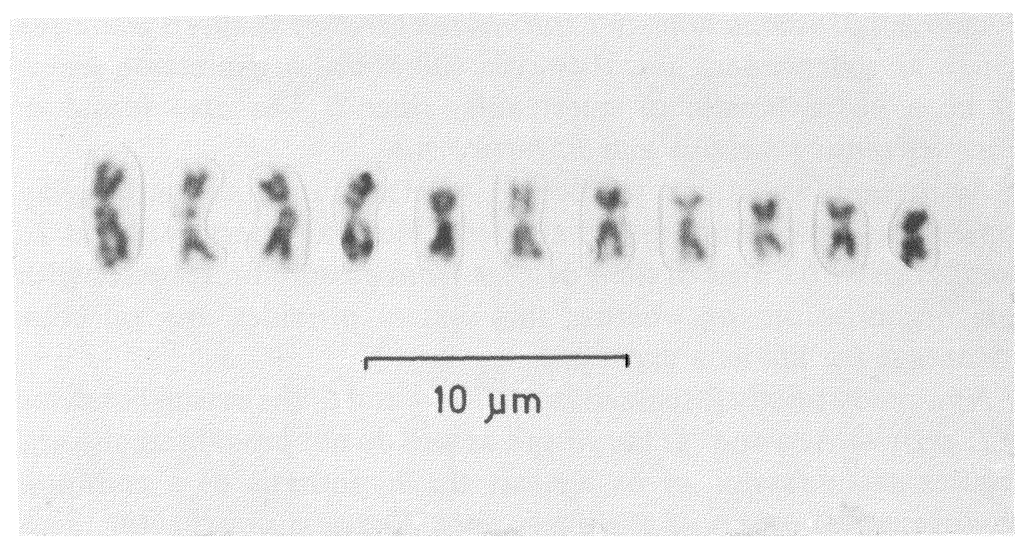

Fig. 3: Karyotype of $L$. provancheri ô with $\mathrm{n}=11$ chromosomes. 


\section{6) Discussion}

The present study has described various aspects of the biology of Leptothorax provancheri. With respect to polymorphsim in the female sex we can confirm the observations of Holliday (1903) with a difference only in the proportion of workers (ergatomorphs) without receptacle. While Holliday found only one such specimen in her large material from Colebrook, Conn., we had 24 workers without a receptacle as compared to 42 ergatomorphs with a receptacle. Furthermore, we found 2 intermorphs, both workerlike, but with ocelli present, without a spermatheca. It is a striking peculiarity of $L$. provancheri that all morphologically different females, from deälate gynomorphs to seemingly normal workers (colony no. 9) may have receptacula and may even function as queens. Sometimes (e.g. colony 9) intermorphs may live in a colony alongside an ergatomorphic queen (presumably their mother!). However, the same observation was made in Formicoxenus nitidulus (Buschinger and Winter 1976), where even sterile gynomorphs may exist in nests with intermorphic queens.

A second striking fact is the presence of one or several inseminated females (not only newly fertilized ones) living together with the one fertile queen. Such a system, functional monogyny, has first been documented, among ants, in Leptothorax gredleri Mayr (Buschinger 1968), an independent ant. However, this social organization seems to be a characteristic of guest ants, since it was also found in Formicoxenus nitidulus and $F$. hirticornis.

At present, we cannot yet decide, whether functional monogyny represents a plesiomorphic character which the guest ants and $L$. gredleri share because of their descent from a common ancestor with this organization, or whether this system provides any selective advantage for life as a guest ant.

As already briefly discussed in section 4 and 5 , the sexual behavior of $L$. provancheri and the karyotype as well do not provide significant arguments in favour of or against the hypothesis of a common phylogenetical origin of the guest ants. The sexual behavior, with females "calling" for males by use of a poison gland secretion as sexual pheromone, is common among Leptothoracini, especially among the social parasitic species.

Thus, our data are not yet sufficient to prove that $L$. provancheri should belong to the genus Formicoxenus, or that there is a closer 
relationship among the guest ants than between these and other Leptothoracini. On the other hand, the observations clearly confirm that $L$. provancheri at least belongs to a group of Leptothoracini assembling around the subgenus Mychothorax (= Leptothorax Smith), a group among which also Formicoxenus, Harpagoxenus and Doronomyrmex have to be classed.

\section{SUMMARY}

L. provancheri was collected from a site in the municipality of StAugustin, Comté de Portneuf, Québec. This guest ant was living together with $M$. incompleta Provancher (=brevinodis Emery). We found several nests within the nesting areas of large, polygynous Myrmica colonies. From dissecting representative samples we conclude that $L$. provancheri has a social organization similar to that of Formicoxenus, a "functional monogyny". This means that each colony unit contains one fully fertile queen, which may be a deälate, an intermorphic, or even ergatomorphic specimen; and several fertilized, but sterile females. We can confirm the observations of Holliday (1903) stating that nearly all female individuals, most ergatomorphs, intermorphs of various degrees, and alate females, possess a well developed spermatheca. Sexually active females exhibit a sexual calling behavior (Locksterzeln) like the one described for Formicoxenus and other social parasites related to the subgenus Leptothorax (= Mychothorax Ruzsky). The haploid chromosome number is 11. This is different from Formicoxenus nitidulus $(\mathrm{n}=15)$. Whether $L$. provancheri belongs to the genus Formicoxenus cannot yet be decided.

\section{Literature Cited}

Buschinger, A., 1968. Mono- und Polygynie bei Arten der Gattung Leptothorax Mayr (Hymenoptera, Formicidae). Ins. soc. 15: 217-226.

1972. Giftdrüsensekret als Sexualpheromon bei der Ameise Harpagoxenus sublaevis. Die Naturwissenschaften 59: 313-314

1976. Giftdrüsensekret als Sexualpheromon bei der Gastameise Formicoxenus nitidulus (Nyl.) (Hym., Form.). Ins. soc. 23: 215-226

1978. Queen polymorphism in ants. Réunion Scientifique de la Section Française UIEIS, 1978, Besançon, Bull. Intérieur 1978: 12-22

1979. Functional monogyny in the American guest ant Formicoxenus hirticornis (Emery) (= Leptothorax hirticornis), (Hym., Formicidae). Ins. soc. 26: $61-68$ 
Buschinger, A. and T. M. Alloway, 1978. Caste polymorphism in Harpagoxenus canadensis M.R.Smith (Hym., Formicidae). Ins. soc. 25: 339-350

Buschinger, A. AND U. Winter, 1976. Funktionelle Monogynie bei der Gastameise Formicoxenus nitidulus (Nyl.) (Hym., Form.) Ins. soc. 23: 549-558

Creighton, W.S., 1950. The Ants of North America. Bull. Mus. Comp. Zool., Harvard Univ. 104: 1-585

EMERY, C., 1895. Beiträge zur Kenntnis der nordamerikanischen Ameisenfauna. Zool. Jb. Syst., Geogr., Biol. Tiere 8: 257-360

GREGG, R.E., 1963. The Ants of Colorado. University of Colorado Press, Boulder. $792 \mathrm{pp}$.

Holliday, M., 1903. A Study of Some Ergatogynic Ants. Zool. Jb. Syst. Ökol. Geogr. Tiere 19: 293-328

Imai, H.T., Crozier, R.H., AND R.W. Taylor, 1977. Karyotype Evolution in Australian Ants. Chromosoma 59: 341-393

Provancher, L, 1881. Faune canadienne. Formicides. Natural. Canad. 12: 353360

1883. Petite faune entomologique du Canada. Vol.2. Darveau, Québec. 831 pp.

Smith, D.R. 1979. Formicidae, in Catalogue of Hymenoptera in America North of Mexico, vol. 2, Apocrita (Aculeata) (K.V. Krombein, ed.) Smithsonian Inst. Washington, D.C. Pp. 1323-1467.

Sмiтн, M.R., 1950. On the Status of Leptothorax Mayr and some of its subgenera. Psyche 57: 29-30

Wheeler, W.M., 1901. The Compound and Mixed Nests of American Ants. Amer. Nat. 35: 431-448

1903. Ethological Observations on an American Ant (Leptothorax emersoni Wheeler). Arch. Psychol. Neurol. 2: 1-31

1907. Notes on a New Guest Ant. Leptothorax glacialis, and the Varieties of Myrmica brevinodis Emery. Bull. Wis. Nat. Hist. Soc. 5: 70-83

1910. Ants. New York and London, XXV +661 pp.

1917. The Mountain Ants of Western North America. Proc. Amer. Acad. Arts Sci. Boston, 52: 457-569 

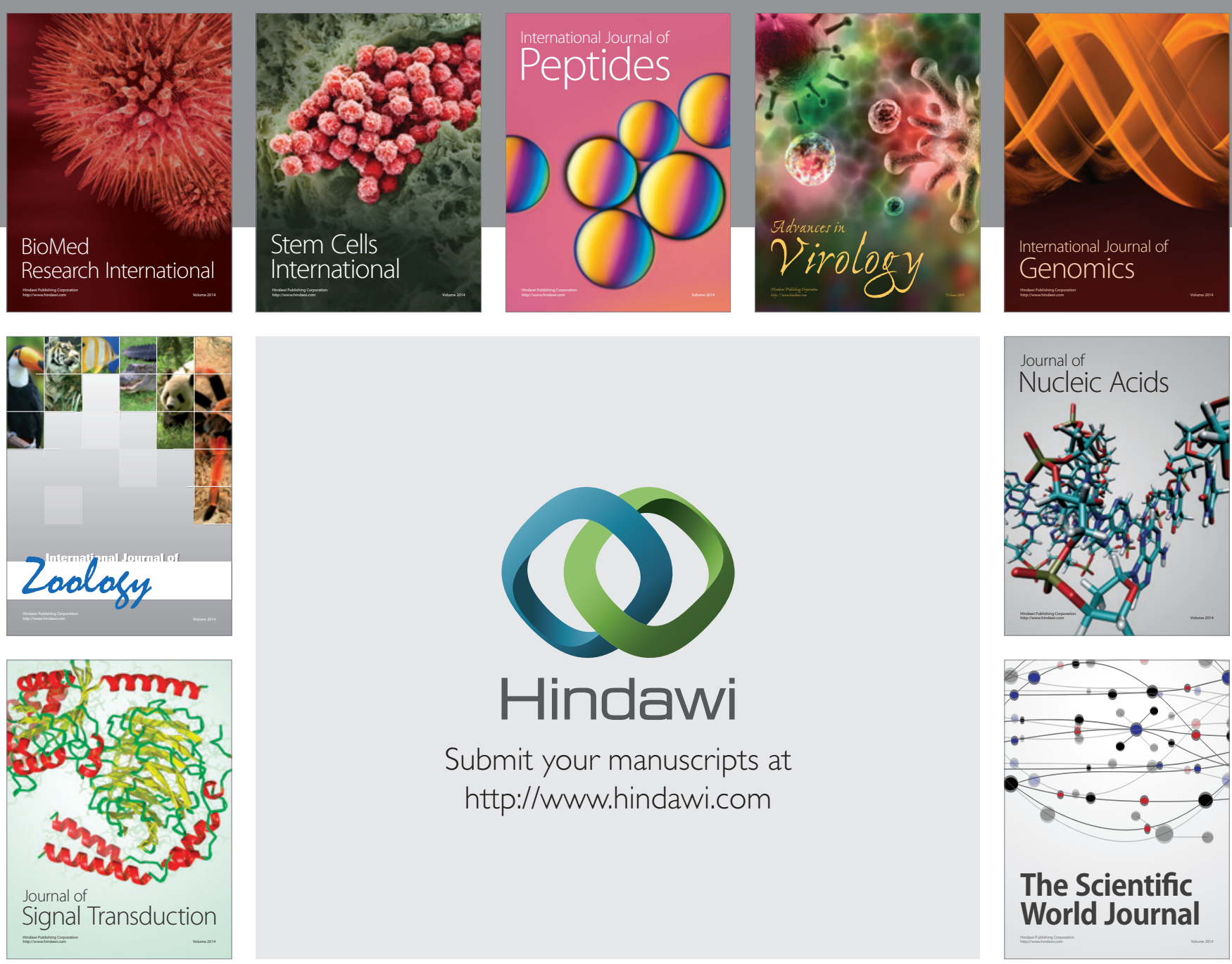

Submit your manuscripts at

http://www.hindawi.com
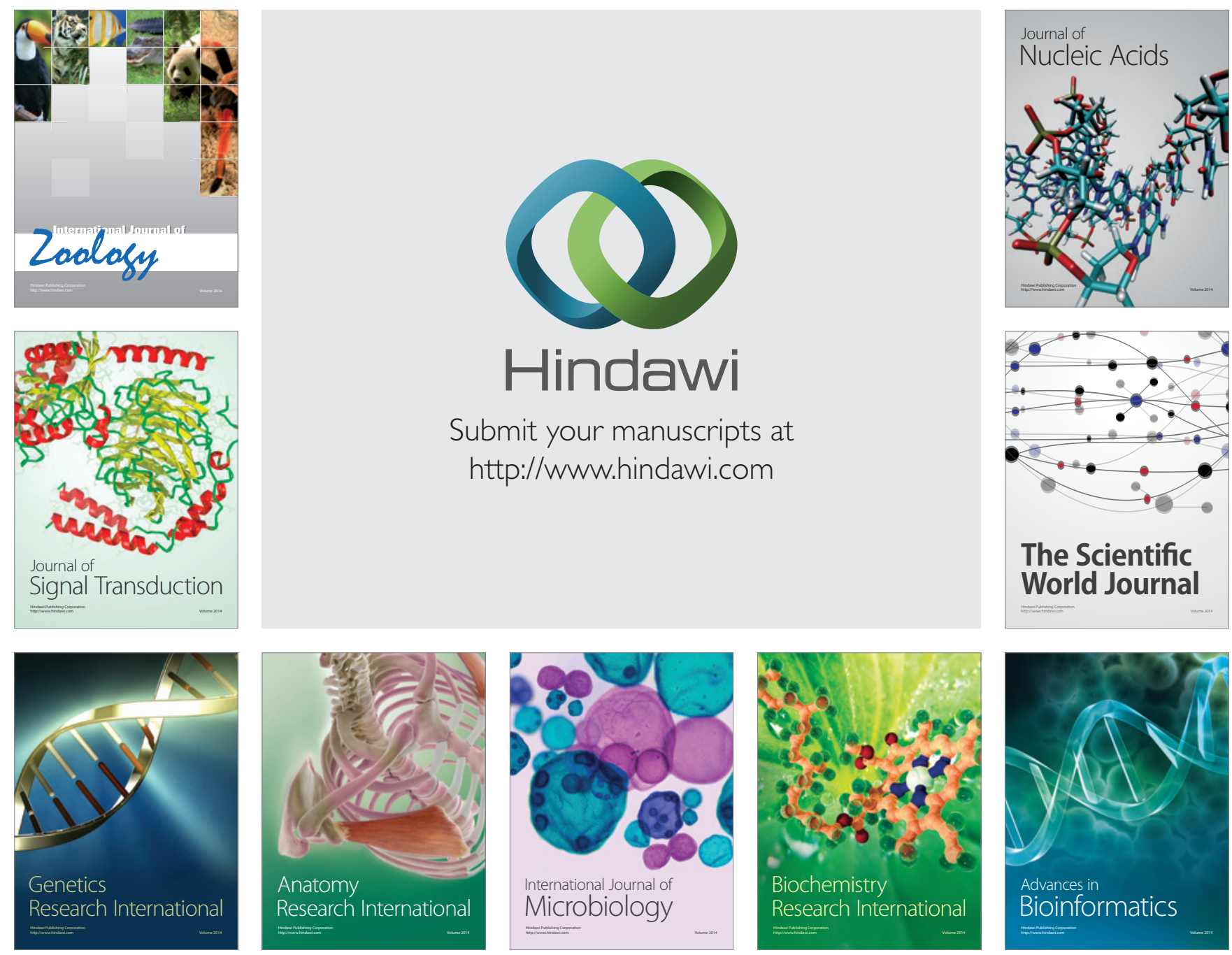

The Scientific World Journal
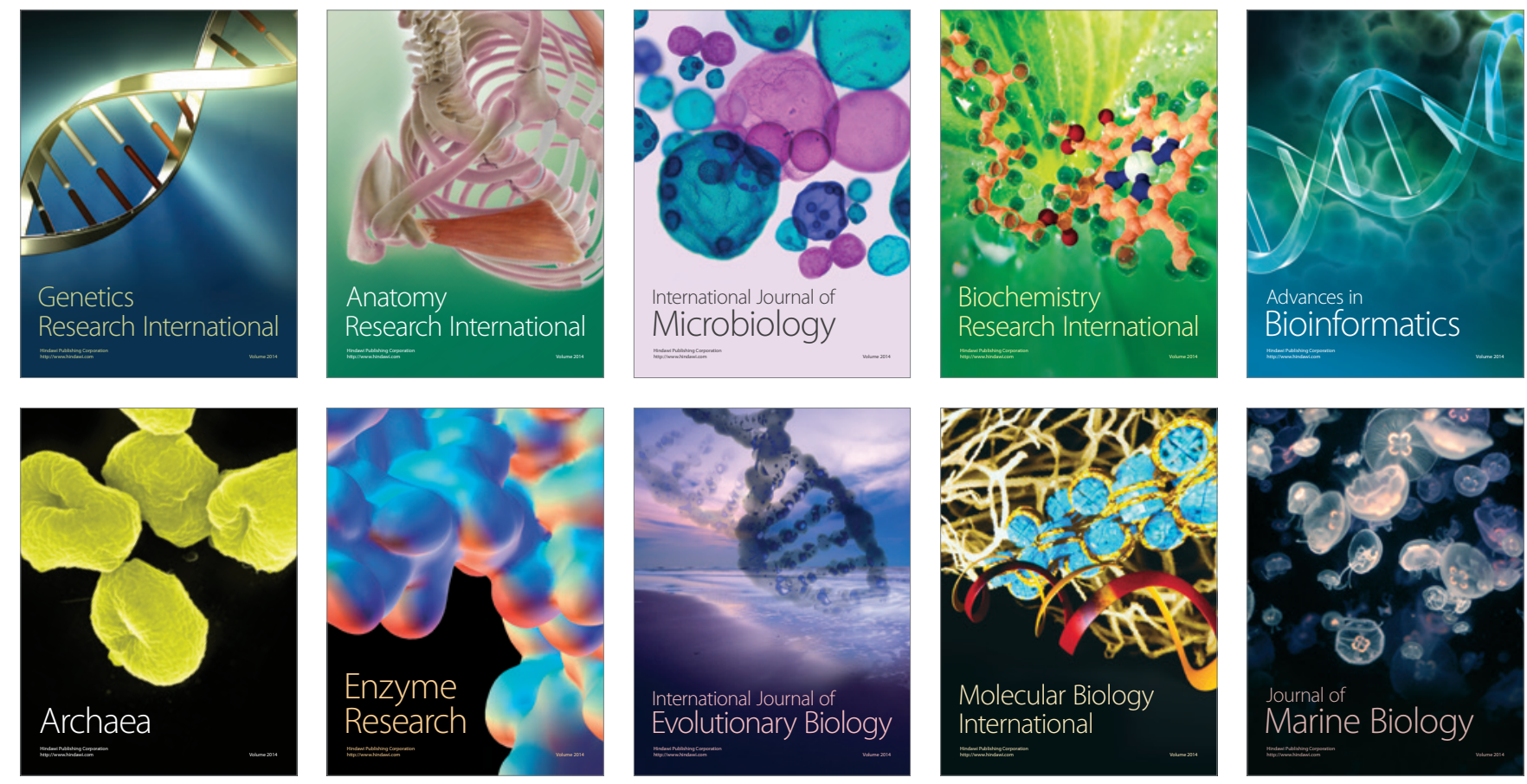